\title{
Bio- and chronostratigraphy of the Middle Triassic Reifling Formation of the westernmost Northern Calcareous Alps
}

\author{
Journal Article \\ Author(s): \\ Brühwiler, Thomas; Hochuli, Peter A.; Mundil, Roland; Schatz, Wolfgang; Brack, Peter \\ Publication date: \\ 2007-12 \\ Permanent link: \\ https://doi.org/10.3929/ethz-b-000158732 \\ Rights / license: \\ In Copyright - Non-Commercial Use Permitted \\ Originally published in: \\ Swiss Journal of Geosciences 100(3), https://doi.org/10.1007/s00015-007-1240-2
}




\title{
Bio- and chronostratigraphy of the Middle Triassic Reifling Formation of the westernmost Northern Calcareous Alps
}

\author{
Thomas Brühwiler ${ }^{1, *}$, Peter A. Hochuli ${ }^{1}$, Roland Mundil $^{2}$, Wolfgang Schatz $^{3} \&$ Peter Brack $^{4}$
}

Keywords: Middle Triassic, Reifling Formation, Buchenstein Formation, biostratigraphy, U/Pb zircon dating

\section{ABSTRACT}

New finds of fossils including bivalves, ammonoids, brachiopods and palynomorphs from the Middle Triassic Reifling Formation significantly improve the age assignment for this unit in Liechtenstein and Vorarlberg. The lower part of the Reifling Formation is tentatively referred to the Late Anisian Paraceratites trinodosus Zone and somewhat older levels, whereas the uppermost part reaches the Ladinian Protrachyceras archelaus Zone (ammonoid zonation). The Middle Triassic successions of the study area are correlated with the coeval South Alpine reference section at Bagolino (Brescian Prealps), which also bears the Ladinian GSSP. The comparison shows that the Reifling Formation in the study area is age-equivalent with the South Alpine Prezzo Limestone and the Buchenstein Formation. A volcanoclastic layer in the upper part of the Reifling Formation at Flexenpass yields a U-Pb zircon age of $239.3+/-0.2 \mathrm{Ma}$. This value is slightly older than previously published minimum ages from equivalent horizons in the Southern Alps; the difference is thought to be mainly due to improved pre-treatment of zircons (annealing/ chemical abrasion), which significantly reduces the effects of $\mathrm{Pb}$ loss. The new radio-isotope age further constrains the stratigraphical age of the Reifling Formation and supports the proposed biostratigraphy-based correlation of Middle Triassic successions in the Eastern and Southern Alps.

\section{ZUSAMMENFASSUNG}

Neue Funde fossiler Muscheln, Ammonoideen, Brachiopoden und Palynomorphen aus der mitteltriassischen Reiflinger Formation verbessern die Altersbestimmung dieser Einheit in Liechtenstein und Vorarlberg massgeblich. Der untere Teil der Formation wird provisorisch zur spätanisischen Paraceratites trinodosus Zone und älteren Horizonten gestellt, während der obere Teil bis in die ladinische Protrachyceras archelaus Zone (Ammonoideen-Zonierung) reicht. Die mitteltriassischen Sedimente des Untersuchungsgebietes werden mit dem Referenzprofil von Bagolino (Brescianer Voralpen) korreliert, welches den GSSP des Ladinian beinhaltet. Dieser Vergleich zeigt, dass die Reiflinger Formation des Untersuchungsgebietes gleich alt wie der Südalpine Prezzokalk und die Buchensteiner Formation ist. Die radiometrische U-Pb-Datierung von Zirkonen aus einer vulkanischen Aschenlage aus dem oberen Teil der Reiflinger Formation am Flexenpass ergibt ein Alter von 239.3 +/- 0.2 Ma. Dieser Wert ist älter als bekannte Minimum-Alter von entsprechenden Horizonten aus den Südalpen, und der Unterschied wird auf die verbesserte Zirkon-Vorbehandlung (Sintern gefolgt von chemischer Abrasion) zurückgeführt, wodurch sich die Effekte von Blei-Verlust massgeblich verringern lassen. Das neue Datum schränkt das stratigraphische Alter der Reiflinger Formation weiter ein und stützt die vorgeschlagene biostratigraphische Korrelation mitteltriassischer Sedimente der Ost- und Südalpen.

\section{Introduction}

The Middle Triassic successions of the Northern Calcareous Alps (NCA) part of the Eastern Alps predominantly consist of shallow marine to basinal carbonates with subordinate intercalations of fine-grained clastic sediments (Tollmann 1985). Platform carbonates and basinal deposits of Anisian to Carnian age occur in different tectonic nappe units but detailed reconstructions of the original platfom-basin configuration are still controversial (see Rüffer \& Bechstädt 1995 for a discussion of the situation in the western NCA).
For the heterogeneous basinal successions biostratigraphical information is as yet patchy and the resolution of published correlations of sections throughout the NCA is rarely better than at a substage level (e.g. Bechstädt \& Mostler 1976). Reliable age control is limited to a small number of horizons bearing age diagnostic macrofossils in a few sections such as those around Grossreifling in the eastern NCA (Summesberger \& Wagner 1972, Tatzreiter 2001 and references therein). Outcrops of pelagic successions including condensed Hallstatt-type limestones in the central NCA (e.g. Mandl 1984) produced Late Anisian to possibly Early Ladinian ammonoids reported

\footnotetext{
${ }^{1}$ Paläontologisches Institut und Museum der Universität Zürich, Karl Schmid-Strasse 4, 8006 Zürich, Switzerland.

${ }^{2}$ Berkeley Geochronology Center, Berkeley, CA 94709, USA.

${ }^{3}$ Didaktikzentrum der ETH Zürich, Sonneggstrasse 63, 8092 Zürich, Switzerland.

${ }^{4}$ Departement Erdwissenschaften, ETH Zürich, 8092 Zürich, Switzerland.

* Corresponding author: Thomas Brühwiler. E-mail: bruehwiler@pim.uzh.ch
} 
long ago (Mojsisovics 1893; Diener 1900). In the southeastern NCA Hallstatt-type limestones alternating with an interval similar to the Reifling Formation also yielded age diagnostic conodonts and daonellas (Leithner \& Krystyn 1984). From the Middle Triassic successions of the NCA north of the Inn Valley information on conodonts is available for a few coherent basinal sections (Bechstädt \& Mostler 1974; Donofrio et al. 1979) as well as for isolated samples (Rüffer 1995). More recent and consistent conodont data, and a record of magnetic reversals, exist for a few sections of Late Anisian-Ladinian pelagic carbonates (Reifling Formation) in the eastern NCA (Gallet et al. 1998).

The Reifling Formation is a key stratigraphical interval of pelagic limestones with potential for significantly improved age calibration. In basinal settings at some distance from coeval carbonate platforms the stratigraphical thickness of this unit seems to show little variation and usually ranges in the order of a few tens of metres. Siliceous nodular limestones of the Reifling Formation represent a peculiar facies, which can hardly be distinguished from nodular limestones of the Buchenstein Formation in the Southern Alps. Both formations also bear discrete layers of acidic volcanoclastic debris, often with a distinct greenish colour. In the Southern Alps several of these so called Pietra Verde layers have been confirmed as primary volcanic ash beds and such tephra layers turned out to be ideal markers for precise correlation of sections up to 200 kilometres apart (Brack \& Rieber 1993; Brack \& Muttoni 2000). Moreover, the stratigraphical distribution of the volcanoclastic layers allowed a geochronological framework to be established on the basis of U-Pb single zircon ages (Mundil et al. 1996a). Therefore, if recorded with sufficient detail, the tuff beds in Middle Triassic successions of the NCA are expected to be similarly useful for correlation and radio-isotope dating.

Although the nature of volcanoclastic beds has long been recognised in the western NCA (Vidal 1953; Miller 1965; Sarnthein 1965, 1966; Hirsch 1966), stratigraphical sections with a published record of tuff layers suitable for layer tracing are rare (e.g. Bechstädt \& Mostler 1974). Only for a restricted area in the westernmost NCA Kobel (1969) was able to convincingly demonstrate the lateral persistence of individual volcanoclastic beds. In the Reifling Formation east of the Inn Valley the thickness and frequency of such layers appear to be reduced. In the eastern NCA Gallet et al. (1998) used three principal tuff markers for the correlation of distinct Reifling intervals. However, in view of the larger number of tuff layers identified in similar successions around Grossreifling (Summesberger \& Wagner 1972) the correlations suggested by Gallet et al. (1998) might be ambiguous.

Since the onset of Triassic research in the Alps the sedimentary units of the NCA have often been compared with the stratigraphically better constrained Middle Triassic sediments of the Southern Alps. This was based mainly on lithological similarities and the comparison of a few fossil levels (e.g. Arthaber 1906; Assereto 1971). More recently, correlations were also proposed for entire depositional sequences (Brand- ner 1984; Rüffer \& Zühlke 1995). However, a quantified assessment and comparison of the platform-basin evolution in the NCA is seriously hampered by the lack of sufficiently precise bio- and/or chronostratigraphical constraints.

In the Southern Alps the age constraints for Middle Triassic sediments have improved, especially in the past two decades. In order to achieve better resolved correlations similar progress is also required for data from the NCA. A re-assessment of available older (bio-)stratigraphical information could help in this context, but substantial progress will depend on the availability of accurately positioned additional fossils. In a step towards this goal we present and discuss new bio- and chronostratigraphical data from the Reifling Formation in the westernmost NCA, i.e. in Vorarlberg (Austria) and Liechtenstein. The new results are then compared with information from the Bagolino reference section in the Lombardian part of the Southern Alps. The study area was chosen because of its relatively uniform sedimentary successions including the basinal Reifling Formation for which essential stratigraphical information was readily available (Hirsch 1966; Kobel 1969). Moreover, recent palaeogeographical reconstructions (Brack et al. 1999) suggest that, in Triassic times, the western NCA were situated closer to the western (i.e. Lombardian) than to any other part of the Southern Alps.

Institutional abbreviation: PIMUZ, Paläontologisches Institut und Museum der Universität Zürich, Switzerland.

\section{Setting, available age information and stratigraphy of the Reifling Formation in the study area}

The Middle Triassic successions of Vorarlberg and Liechtenstein are relatively uniform, whereas the basinal successions in the NCA east of the Arlberg pass are often replaced by platform carbonates. The scarce diagnostic fossils provide only a coarse stratigraphical framework for these sediments. A no longer available single and presumably questionable specimen of the ammonoid "Protrachyceras reitzi", as well as data on daonellas (Daonella cf. indica) and conodonts (Gladigondolella tethydis), suggest that the Anisian-Ladinian boundary is within the upper Reifling Formation (Trümpy 1916; Hirsch 1966; Kobel 1969). In analogy with the Southern Alps the occurrence of volcanoclastic layers in the upper Reifling Formation has also been considered an argument for an age of these beds close to the stage boundary.

For the present research stratigraphical successions have been studied in detail at the following sites (Fig. 1): Kulm near Triesenberg (Liechtenstein) (N4707'11“ E09³3'43“ " [WGS 84]), Nospitz near Malbun (Liechtenstein) (N4705'34“ E09 35'54“), Blankuskopf south of Nenzing (western Vorarl-

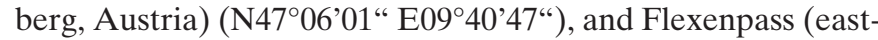

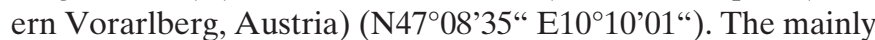
lithostratigraphical results of Hirsch (1966) and Kobel (1969) demonstrate that the pelagic Reifling Formation is bracketed by the shallow basinal carbonates of the Virgloria Formation 


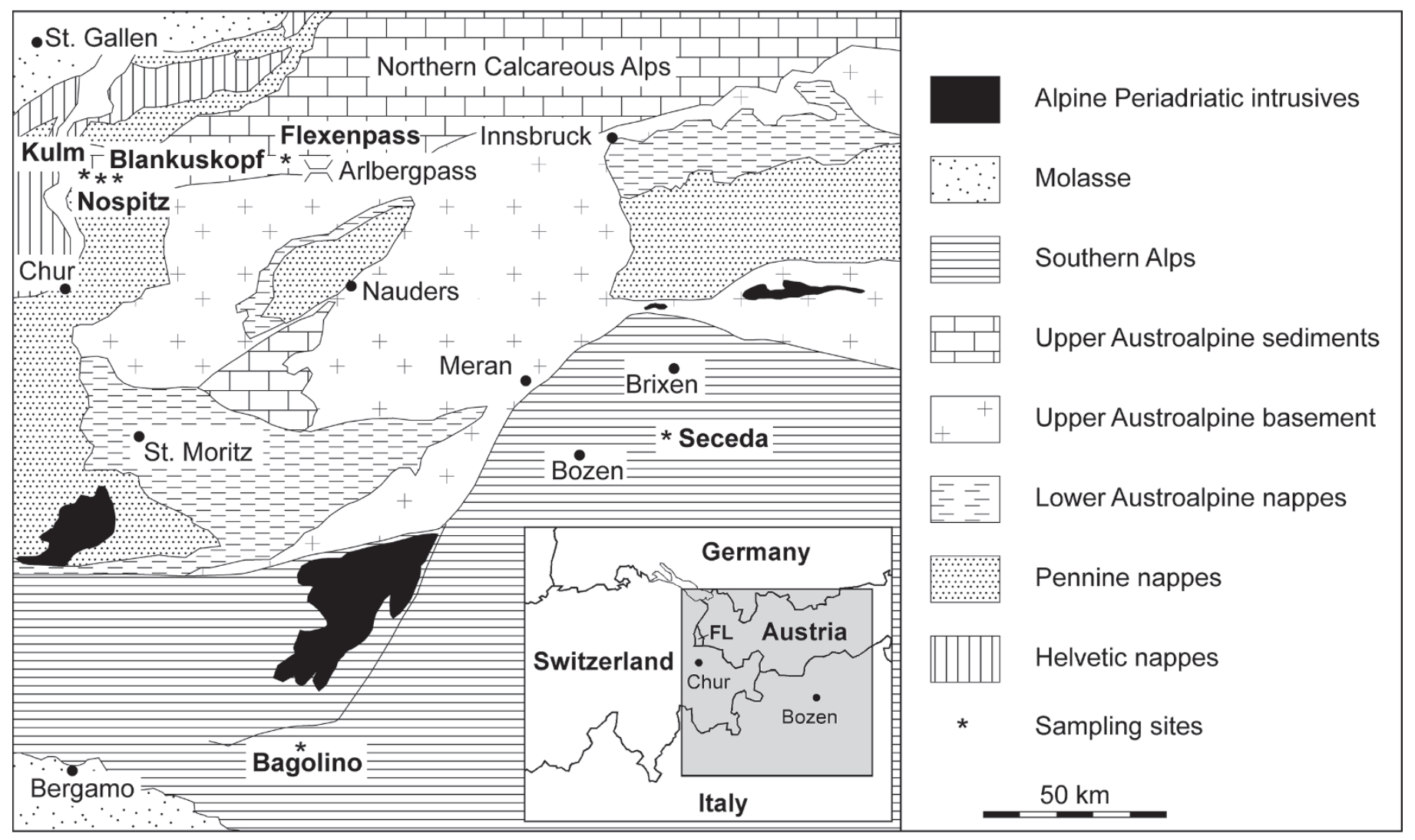

Fig. 1. Tectonic sketch map of eastern Switzerland, Liechtenstein, western Austria and northern Italy with the location of the studied sections. Tectonic map adapted from Gwinner (1971).

(below) and the dark shales and marls of the Partnach Formation (above). Here we adopt the stratigraphical denominations proposed by Bechstädt \& Mostler (1974), who suggest using the name Virgloria instead of Gutenstein sensu Hirsch (1966) and Kobel (1969).

The Reifling Formation represents the upper part of the so-called "Alpine Muschelkalk" (see Kobel 1969 for a review and further sedimentological details) and it consists of nodular, micritic limestone beds, which, in their upper portion, show abundant chert in diffuse patches, bands and in distinct nodules. Following Hirsch (1966) and Bechstädt \& Mostler (1974) the base of the Reifling Formation is defined at the upper boundary of a several metres thick horizon rich in crinoids [note that Kobel (1969) includes this level in his "Reifling Beds"]. Close to the top of the Reifling Formation a prominent 2-5 metres thick interval of Partnach-type shale is intercalated in the nodular limestones. These two distinct lithological markers bracket the Reifling Formation and can be recognised throughout Liechtenstein and Vorarlberg. In its upper half the formation also contains $\mathrm{cm}$ - to $\mathrm{dm}$-thick volcanoclastic ash beds (Pietra Verde) and distinct bedding patterns of some of these layers allow an unambiguous correlation of the studied sections (Fig. 2).

\section{New biostratigraphical data from the Reifling Formation and possible correlations with the Southern Alps}

\section{Macrofossils}

In the studied sections macrofossils are generally very rare. Nevertheless, intense searching yielded a few bivalves, ammonoids and brachiopods (Plate I). Within the Blankuskopf section the brachiopod Piarorhynchella trinodosi is abundant in the lowermost part of the Reifling Formation. Only poorly preserved brachiopods were observed in the corresponding interval at Flexenpass. In the middle part of the Reifling Formation at Flexenpass a single specimen of Daonella cf. longobardica was found. More importantly, in all studied sections a horizon rich in the bivalve Daonella tyrolensis was observed in the upper part of the Reifling Formation, i.e. about $2 \mathrm{~m}$ below the laterally continuous, distinct interval of Partnach-type shales. At Kulm and Nospitz the shale interval also yielded some small ammonoids: several individuals of arcestids and a single specimen assigned to ?Arpadites sp..

The brachiopod Piarorhynchella trinodosi typically occurs throughout the South Alpine Prezzo Limestone (Gaetani 1969). This unit corresponds to the Paraceratites trinodosus 


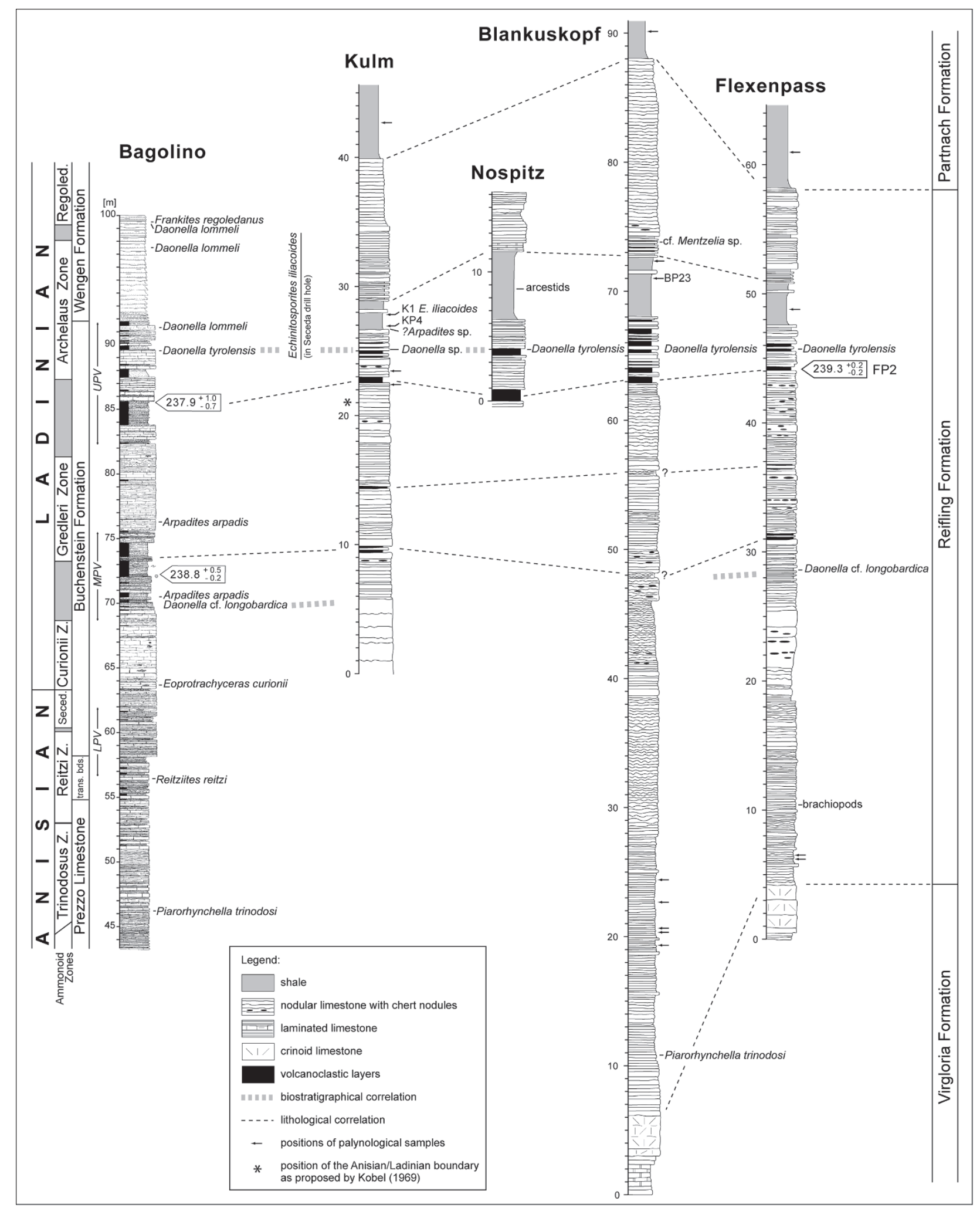

Fig. 2. Correlation of the studied sections of the Reifling Formation in the Northern Calcareous Alps (Liechtenstein, Western Austria) and their comparison with the South Alpine pelagic succession straddling the Ladinian GSSP at Bagolino (Northern Italy; for details see Brack et al. 2005; 0-m-level of Bagolino column corresponds to the base of the Prezzo Limestone). The main intervals with volcanoclastic layers in the Bagolino section are indicated as follows: LPV, MPV, UPV = Lower, Middle, Upper Pietra Verde respectively. Positions of seventeen palynological samples are indicated, six other analysed samples (yielding no palynomorph) come from the lower and middle part of the Partnach Formation at Blankuskopf. See text for a discussion of the radio-isotope ages. 
Zone and older levels. The lower part of the Reifling Formation including the layers with $P$. trinodosi may thus correspond to this time interval.

Because of their global distribution and the presumably short ranges the thin-shelled bivalves of the subgenus Daonella have a high potential for biostratigraphical correlation of Middle Triassic sediments (Schatz 2001, 2004, 2005). Based on the stratigraphical distribution of different species of Daonella, Schatz suggested a Daonella-based biozonation for the Middle Triassic of the Southern Alps.

The species Daonella longobardica is best known from Ladinian platform slope carbonates in the western Southern Alps (Esino Limestone of the Bergamask Alps). In the Bagolino section specimens identified by Schatz (2005) as D. cf. longobardica occur in a distinct horizon of the middle Buchenstein Formation, i.e. at the transition of the Eoprotrachyceras curionii to the Protrachyceras gredleri ammonoid zones. These Daonella from Bagolino seem to be identical with a specimen from Flexenpass. The level with $D$. cf. longobardica at Flexenpass lies $2.5 \mathrm{~m}$ below a distinct thin volcanoclastic layer, which is here tentatively correlated with layers in the Middle Pietra Verde (MPV) interval at Bagolino (Fig. 2).

According to Schatz (2004) the distribution of Daonella tyrolensis is limited to the boundary interval between the Daonella pichleri Zone and the Daonella lommeli Zone, as defined in South Alpine sections (Bagolino, Seceda) and corresponding to the lowermost part of the Protrachyceras archelaus ammonoid Zone. Consequently the horizon with abundant Daonella tyrolensis in the upper part of the Reifling Formation is correlated with the uppermost Buchenstein Formation at Bagolino. This correlation is supported by the occurrence of the ammonoid ?Arpadites sp. in the shale interval close to the top of the Reifling Formation. In the Southern Alps ammonoids of this genus are thought to range from the $P$. gredleri to the $P$. archelaus zones (Brack \& Rieber 1993).

A consequence of the new biostratigraphical results is the significant lowering of the position of the Anisian/Ladinian boundary when compared with Kobel (1969) who drew this limit above the 20m-level in the Kulm-section (Fig. 2). The stage boundary cannot yet be located precisely, but most likely falls in the interval below the layer with Daonella cf. longobardica. Moreover, the attribution to "Protrachyceras reitzi" of the lost ammonoid specimen collected by Trümpy (1916) cannot be confirmed in view of its stratigraphical position above the Partnach-type shale interval in the uppermost Reifling Formation. In the Southern Alps and in Hungary the species Reitziites reitzi is restricted to a narrow stratigraphical interval well below the Anisian/Ladinian boundary (cf. Bagolino column in Figure 2).

\section{Palynology}

Twenty three samples taken from different stratigraphical levels in the Reifling Formation and the Partnach Formation from the Kulm, Blankuskopf and the Flexenpass sections (Fig. 2) were treated by standard $\mathrm{HCl}, \mathrm{HF}$ and $\mathrm{HNO}_{3}$ preparation methods and studied for their palynological content. Due to strong thermal alteration (see also Petschik 1989 and Ferreiro Mählmann 1994) no palynomorph could be determined in samples from Flexenpass, whereas no significant alteration was observed in samples from Kulm and Blankuskopf. However, most samples from these localities show strongly degraded organic matter of variable quality of preservation. Only three samples from the shale interval in the upper part of the Reifling Formation (Fig. 2) provided palynomorphs suitable for determination (Plate II). Apart from pollen and spores these samples contain rich assemblages of acritarchs.

Sample KP 4 from Kulm (Fig. 2) yielded a few palynomorphs (Calamospora sp., Baculatisporites sp., ?Lycopodiacidites sp.) as well as several acritarchs. The following palynomorphs were detected in sample $\mathrm{K} 1$ from the same section (Fig. 2, Plate II): Aratrisporites scabratus KLAUs 1960, Aratrisporites cf. parvispinosus LESCHIK 1955, Ovalipollis sp., ?Triadispora sp., Striatoabieites sp., Staurosaccites sp., Endosporites sp., Nevesisporites vallatus DE JERSEY \& PATEN 1964, Microcachryidites sp., Verrucosisporites sp., Duplicisporites granulatus (LESCHIK 1955) VAN DER EEM 1983, Calamospora sp., Porcellispora longdonensis (CLARKE 1965) SCHEURING 1970, Gordonispora fossulata (BALME 1970) VAN DER EEM 1983, ?Enzonalasporites sp., ?Cyclotriletes sp., ?Infernopollenites sp., Baculatisporites sp., Deltoidospora sp., Concavisporites sp., Camerosporites secatus LESCHIK 1955, Echinitosporites iliacoides SCHULZ \& KRUTZSCH 1961, and several acritarchs. Sample BP 23 from Blankuskopf (Fig. 2) contains Ovalipollis sp., Circumpolles (Partitisporites sp., Duplicisporites sp., Paracirculina sp., ?Advisisporites sp.), ?Triadispora sp., Aratrisporites sp., Nevesisporites vallatus, Todisporites sp., Cycadopites sp., Ephedripites sp., Deltoidospora sp., and several acritarchs.

The stratigraphical distribution of spores and pollen in Middle Triassic successions of the Southern Alps and Hungary allowed Van der Eem (1983) and Brugman (1986) to establish discrete palynological phases. New results from the Seceda drill core (Brack et al. 2000; Hochuli \& Roghi 2002) now provide an improved intercalibration of palynological data with ammonoid biostratigraphy. According to Van der Eem (1983) and Brugman (1986) the palynomorphs Camerosporites secatus, Nevesisporites vallatus and Duplicisporites granulatus first appear at the base of the plurianulatus-secatus phase. The base of this phase was originally correlated with the base of the Eoprotrachyceras curionii ammonoid Zone (Brugman 1986). However, new data from Seceda suggest that the plurianulatus-secatus phase more likely corresponds to the Protrachyceras gredleri ammonoid Zone (Hochuli \& Roghi 2002). The species Echinitosporites iliacoides is an important stratigraphical marker with a range limited to the secatus-dimorphus phase of Van der Eem (1983). According to Brugman (1986), this phase corresponds to the $P$. gredleri and $P$. archelaus zones, but new data from the Seceda core show that E. iliacoides is 


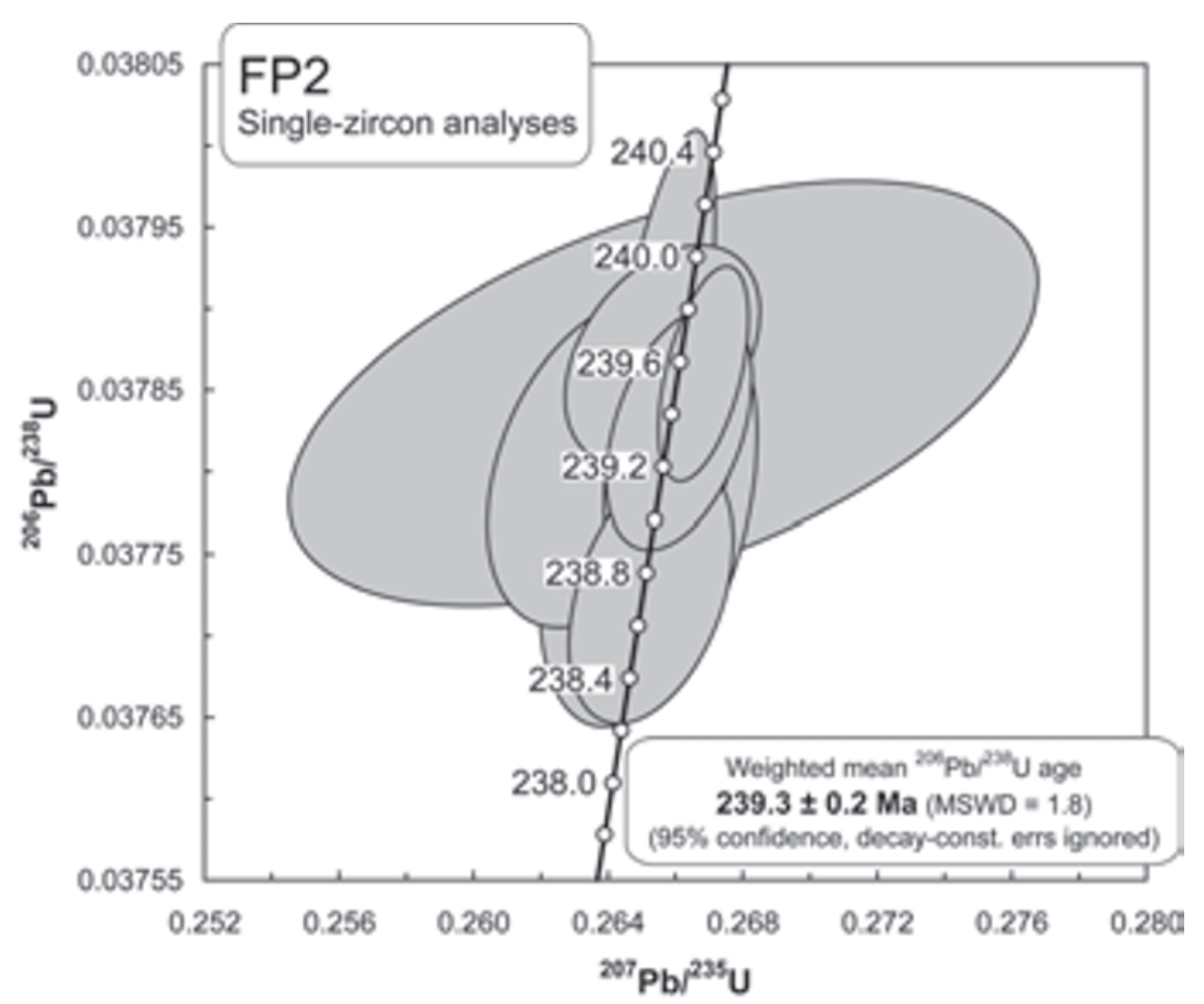

Fig. 3. Concordia diagram of analyses of zircons $\left({ }^{206} \mathrm{~Pb} /{ }^{238} \mathrm{U}\right.$ vs. $\left.{ }^{207} \mathrm{~Pb} /{ }^{235} \mathrm{U}\right)$ from the sample $\mathrm{FP} 2$ of the Flexenpass section (Reifling Formation, Northern Calcareous Alps, Austria). Data-point error ellipses are $2 \sigma$. restricted to the Protrachyceras archelaus Zone (Hochuli \& Roghi 2002). The shale interval close to the top of the Reifling Formation, yielding Camerosporites secatus, Nevesisporites vallatus, Duplicisporites granulatus and Echinitosporites iliacoides, can be assigned to the Protrachyceras archelaus Zone supporting the suggested correlation of the uppermost Reifling and Buchenstein Formations.

\section{Litho-biostratigraphical correlation of the studied sections with South Alpine successions}

The basinal Middle Triassic successions of eastern Lombardy and Giudicarie (Southern Alps) show the following stratigraphical order of formations (Assereto \& Casati 1965, for a general stratigraphical scheme see also figure 2 in Brack \& Rieber 1993): i) shallow marine Angolo Limestone, ii) pelagic Prezzo Limestone and Buchenstein Formation, and iii) clastic sediments of the Wengen Formation. The corresponding successions of the western NCA are similar in that the shallowmarine Virgloria Formation is followed by the deep-water Reifling Formation, which in turn is overlain by the clastic sediments of the Partnach Formation. In addition to this common overall trend of stratigraphical successions, some peculiar lithologies show striking similarities. Close analogies exist between the "Wurstelkalk"-intervals of the Virgloria (and Gutenstein) Formation and the strongly bioturbated and nodular intervals in the Angolo Limestone of eastern Lombardy. The top part of both units is often characterised by crinoid beds and/or brachiopod-lumachella. The nodular lower Reifling Formation resembles the shale-poor nodular varieties of the Prezzo Limestone (e.g. in the Bagolino section) and the siliceous nodular limestones of the Reifling Formation are hard to distinguish from their counterparts in the Buchenstein Formation. Moreover, both units also contain volcanoclastic ash layers at different stratigraphical levels. The marls and shales of the Partnach Formation appear to be finer-grained when compared with the siliciclastic Lombardian Wengen Formation of latest Ladinian age. Lithologically similar to the Partnach shales are the local occurrences of the Lozio shales in the Southern Alps. The latter unit is restricted to exposures around the middle Val Camonica and situated stratigraphically above the Wengen Formation. Its base is already Carnian in age (Balini et al. 2000). Because no detailed biostratigraphical constraints are available for the Partnach Formation its correspondence with a distinct stratigraphical unit in the Southern Alps remains open.

In sections straddling the entire South Alpine Buchenstein Formation volcanoclastic layers are usually concentrated in three intervals: the Lower (LPV), the Middle (MPV) and the Upper Pietra Verde (UPV) (Brack \& Muttoni 2000; Muttoni et al. 2004). Although volcanoclastic beds of the western NCA cannot be correlated on a layer basis, the two distinct intervals with Pietra Verde in the studied Reifling intervals (around the $31 \mathrm{~m}$-level and between 44-46 $\mathrm{m}$ at Flexenpass) seem to correspond to the MPV and UPV, respectively (Fig. 2). This is in agreement with the biostratigraphical constraints. 
The proposed correlation implies that the thickness values of corresponding intervals show little variation, not only within the westernmost NCA, but they also hardly differ from those of the Bagolino section, suggesting that the depositional setting and the sources of the pelagic sediments may have been uniform throughout large areas. On the basis of estimates made on Buchenstein sections in the Southern Alps (Brack \& Muttoni 2000; Brack et al. 2007) the net rate of (not decompacted) sediment accumulation of the nodular limestone facies of the Buchenstein Formation at Bagolino ranges between 5-10 m/Ma. The thickness of Pietra Verde layers is in most cases reduced in the NCA when compared with the South Alpine equivalents. This may be explained with a larger distance to the main centres of eruption.

\section{$\mathrm{U} / \mathrm{Pb}$ radio-isotopic dating of a tuff layer at Flexenpass: methods, results and comparison with data from the Southern Alps}

Zircons from a volcanoclastic ash layer from the Flexenpass section (Fig. 2, $44.3 \mathrm{~m}$ level, horizon 12 in Hirsch 1966) were extracted by standard mineral separation techniques for $\mathrm{U} / \mathrm{Pb}$ dating. The analyzed bed is about $30 \mathrm{~cm}$ thick and consists of well preserved, greenish material referred to as Pietra Verde (Hirsch 1966; Kobel 1969; Obenholzner 1991). The volcanoclastic layer shows distinct graded bedding with a few centimetres thick sandy layer at the base followed by siltstone.

Individual zircon grains were selected using transmitted light microscopy. Only euhedral, clear grains devoid of optically recognizable cores were chosen for analysis. All zircons were treated using the method of thermal annealing at $850^{\circ} \mathrm{C}$ for $36 \mathrm{hrs}$, followed by chemical abrasion with conc. HF in pressurised dissolution capsules at $220^{\circ} \mathrm{C}$ for $16 \mathrm{hrs}$ in order to remove crystal portions affected by secondary $\mathrm{Pb}$ loss (Mundil et al. 2004; Mattinson 2005). Prior to dissolution the crystals were: (1) rinsed several times in conc. $\mathrm{HNO}_{3}$, (2) cleaned in ultrasonically agitated aqua regia followed by several steps in clean $\mathrm{HNO}_{3}$. Zircons were then transferred to perforated miniature PTFE capsules and spiked with ${ }^{205} \mathrm{~Pb}-{ }^{233} \mathrm{U}-{ }^{235} \mathrm{U}$ tracer solution. The capsules were placed on an elevated rack in a $125 \mathrm{ml}$ digestion vessel, allowing vapour transfer dissolution in a mixture of $50 \% \mathrm{HF} /$ conc. $\mathrm{HNO}_{3}(30 / 1)$ at $220^{\circ} \mathrm{C}$ for 6 days. After dissolution the dried sample/tracer mixture was taken up in $20 \mu \mathrm{l} 3 \mathrm{M} \mathrm{HCl}+5 \mu \mathrm{l} 0.25 \mathrm{M} \mathrm{H}_{3} \mathrm{PO}_{4}$, dried down, and loaded together with silica gel $+\mathrm{H}_{3} \mathrm{PO}_{4}$ on out-gassed $\mathrm{Re}$ filaments. Isotope ratios were determined on a Micromass Sector 54 mass spectrometer using a Daly-type ion counter positioned behind a WARP filter. $\mathrm{Pb}\left(\right.$ as $\left.\mathrm{Pb}^{+}\right)$and $\mathrm{U}\left(\right.$ as $\mathrm{UO}_{2}{ }^{+}$) were run sequentially on the same filament. The ${ }^{205} \mathrm{~Pb}-{ }^{233} \mathrm{U}-$ ${ }^{235} \mathrm{U}$ tracer solution was calibrated repeatedly against solutions derived from certified standards of isotopically pure ${ }^{206} \mathrm{~Pb}$ and natural U (NIST SRM-991 and CRM-145, respectively). To provide the highest level of confidence in the tracer calibration the standard solutions were themselves checked against solutions prepared from other NIST-certified standards (NBLCRM111- A ${ }^{233}$ U, NBL-CRM135 ${ }^{235}$ U NIST SRM-981 and NIST SRM-982). All of these calibrations (effectively three independent calibrations each for $\mathrm{U}$ and for $\mathrm{Pb}$ ) agreed within the precision of the measurements, so that we are confident of tracer $\mathrm{Pb} / \mathrm{U}$ to within $0.15 \%$. In addition our tracer solution was checked against the similarly-calibrated tracer solution used at IGMR, ETH Zürich (itself checked against the tracer solution of the Royal Ontario Museum, as well as several other laboratories (Wiedenbeck et al. 1995). No inter-laboratory bias was detected by these cross-checks. In addition a cross check of the tracer (and entire procedure), involving the comparison of zircon $\mathrm{U} / \mathrm{Pb}$ ages for the same rock (R33) between BGC and the ROM, showed agreement at the 1 permil level (Black et al. 2004) and most recently, an intercalibration study involving several laboratories, including the BGC, using zircons from R33 showed no significant inter-laboratory bias (say below the 2 permil level, Condon et al. 2005). Repeat measurements of the total procedural blank averaged $0.8 \pm 0.3$ pg $\mathrm{Pb}$ ( $\mathrm{U}$ blanks were indistinguishable from zero), with ${ }^{206} \mathrm{~Pb} /{ }^{204} \mathrm{~Pb}=18.55 \pm 0.63,{ }^{207} \mathrm{~Pb} /{ }^{204} \mathrm{~Pb}=15.50 \pm 0.55,{ }^{208} \mathrm{~Pb} / 204 \mathrm{~Pb}$ $=38.07 \pm 1.56$ (all $2 \sigma$ of population), and a ${ }^{206} \mathrm{~Pb} /{ }^{204} \mathrm{~Pb}$ ${ }^{207} \mathrm{~Pb} /{ }^{204} \mathrm{~Pb}$ correlation of +0.9 . These ratios and uncertainties were propagated into the age and age-error calculations. Common $\mathrm{Pb}$ in excess of the analytical blank was assumed to have the same composition as given above, since using blank $\mathrm{Pb}$ or average $240 \mathrm{Ma}$ crustal $\mathrm{Pb}$ has essentially no effect on the final result. Mass fractionation of $\mathrm{U}$ during analysis was controlled by the $\mathrm{U}$ double spike, whereas $\mathrm{Pb}$ mass fractionation was corrected by $0.15 \pm 0.9 \% / A M U$ (based on multiple analyses of NBS 981).

The $U$ concentration of the analyzed zircons ranges between 200 and 660 ppm with one outlier containing 2200 ppm (Z03). Th/U varies from 0.27 to 0.39 . Nine single zircons from a $5 \mathrm{~kg}$ rock sample were analysed yielding a weighted ${ }^{206} \mathrm{~Pb} /{ }^{238} \mathrm{U}$ mean age of $239.3 \pm \mathbf{0 . 2}$ Ma (MSWD 1.8; the uncertainty is augmented to $\pm 0.6 \mathrm{Ma}$ if an additional $0.15 \%$ from tracer calibration is included for comparison with the ages in Mundil et al. (1996a) (Table 1 and Fig. 3). The U/Pb zircon ages of Pietra Verde horizons within the P. gredleri and $P$. archelaus zones at Bagolino and Seceda are slightly younger (BAG.06a, BAG.07, SEC.21 dated to 238.8 +.5/-.2 Ma, 237.9 +1.0/-.7 Ma, 238.0 +.4/-.7 Ma in Mundil et al. (1996a, b; see also Fig. 2). This is due to remaining effects of $\mathrm{Pb}$ loss, which has not been successfully removed by the then standard technique of air abrasion (Krogh 1982). Accounting for this complication the latter ages were deemed minimum ages in Mundil et al. (1996a). The recent re-analysis of a Latemar sample (Brack et al. 2007) shows that similar shifts towards slightly older ages may be expected also for values obtained on older levels in the Buchenstein Formation and at Latemar (Mundil et al. 1996a, 2003). Therefore we are confident that our new radio-isotopic age from Flexenpass is consistent with the bio- and lithostratigraphy-based correlation of the upper Reifling and the Buchenstein Formations. 
Table 1. U-Pb isotopic data of zircons from the sample FP2 of the Flexenpass section (Reifling Formation, Northern Calcareous Alps, Austria).

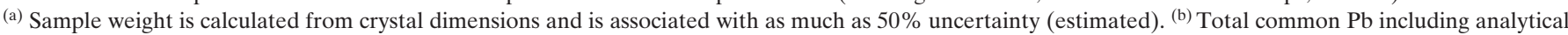

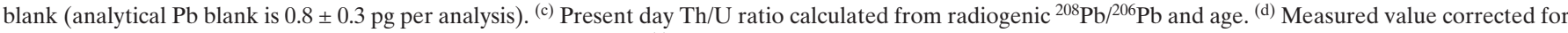

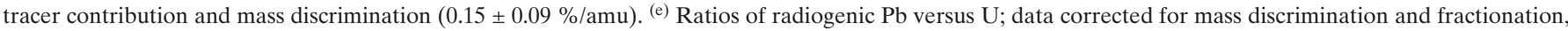
tracer contribution and common $\mathrm{Pb}$ contribution. ${ }^{(\mathrm{f})}$ Correlation coefficient of radiogenic ${ }^{207} \mathrm{~Pb} /{ }^{235} \mathrm{U}$ versus ${ }^{206} \mathrm{~Pb} /{ }^{238} \mathrm{U}$.

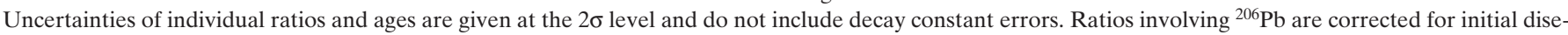

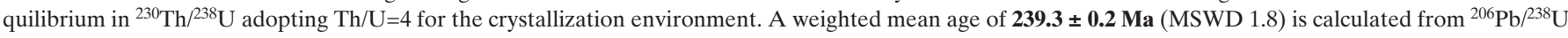
ages of individual analyses.

\begin{tabular}{|c|c|c|c|c|c|c|c|c|c|c|c|c|c|c|c|}
\hline \multirow{3}{*}{ Sample } & \multirow{3}{*}{$\begin{array}{l}\mu g^{(a)} \\
\text { zirc. }\end{array}$} & \multirow{3}{*}{$\begin{array}{c}\text { ppm } \\
\mathrm{U}\end{array}$} & \multirow{3}{*}{$\begin{array}{c}\mathrm{Pb}_{\mathrm{c} .}{ }^{(\mathrm{b})} \\
(\mathrm{pg})\end{array}$} & \multirow{3}{*}{$\frac{\mathrm{Th}^{(\mathrm{c})}}{\mathrm{U}}$} & \multicolumn{7}{|c|}{ isotopic ratios } & \multirow[b]{3}{*}{$\rho^{(\mathrm{f})}$} & \multicolumn{3}{|c|}{ isotopic ages } \\
\hline & & & & & ${ }^{206} \mathrm{~Pb}^{(\mathrm{d})}$ & ${ }^{207} \mathrm{~Pb}^{(\mathrm{e})}$ & \pm & ${ }^{207} \mathrm{~Pb}^{(\mathrm{e})}$ & \pm & ${ }^{206} \mathrm{~Pb}^{(\mathrm{e})}$ & \pm & & ${ }^{206} \mathrm{~Pb}$ & ${ }^{207} \mathrm{~Pb}$ & ${ }^{207} \mathrm{~Pb}$ \\
\hline & & & & & ${ }^{204} \mathrm{~Pb}$ & ${ }^{206} \mathrm{~Pb}$ & $\%$ & ${ }^{235} \mathrm{U}$ & $\%$ & ${ }^{238} \mathrm{U}$ & $\%$ & & ${ }^{238} \mathrm{U}$ & ${ }^{235} \mathrm{U}$ & $\overline{{ }^{206} \mathrm{~Pb}}$ \\
\hline FP2.Z02 & 1,7 & 312 & 0,8 & 0,37 & 1637 & 0,05101 & 0,7 & 0,2653 & 0,7 & 0,03773 & 0,17 & 0,39 & $238.7 \pm 0.4$ & $239.0 \pm 1.8$ & $241.2 \pm 16.0$ \\
\hline FP2.Z03 & 0,7 & 2184 & 1,1 & 0,39 & 3170 & 0,05086 & 0,4 & 0,2654 & 0,6 & 0,03785 & 0,35 & 0,68 & $239.5 \pm 0.8$ & $239.0 \pm 1.3$ & $234.6 \pm 9.4$ \\
\hline FP2.Z04 & 0,4 & 284 & 0,8 & 0,37 & 348 & 0,05091 & 3,3 & 0,2657 & 3,4 & 0,03785 & 0,28 & 0,51 & $239.5 \pm 0.7$ & $239.2 \pm 8.1$ & $236.8 \pm 75.2$ \\
\hline FP2.Z06 & 2,4 & 196 & 1,0 & 0,33 & 1156 & 0,05062 & 1,0 & 0,2639 & 1,0 & 0,03780 & 0,22 & 0,38 & $239.2 \pm 0.5$ & $237.8 \pm 2.5$ & $223.5 \pm 22.6$ \\
\hline FP2.Z21 & 1,7 & 659 & 0,8 & 0,27 & 3513 & 0,05112 & 0,4 & 0,2669 & 0,4 & 0,03786 & 0,14 & 0,52 & $239.5 \pm 0.3$ & $240.2 \pm 1.0$ & $246.5 \pm 8.2$ \\
\hline FP2.Z22 & 2,3 & 300 & 0,9 & 0,38 & 1835 & 0,05103 & 0,6 & 0,2662 & 0,7 & 0,03783 & 0,16 & 0,41 & $239.3 \pm 0.4$ & $239.6 \pm 1.6$ & $242.4 \pm 14.1$ \\
\hline FP2.Z23 & 1,3 & 424 & 0,7 & 0,37 & 1870 & 0,05102 & 0,6 & 0,2660 & 0,6 & 0,03782 & 0,19 & 0,44 & $239.3 \pm 0.5$ & $239.5 \pm 1.5$ & $241.6 \pm 13.4$ \\
\hline FP2.Z24 & 2,3 & 381 & 1,6 & 0,35 & 1304 & 0,05093 & 0,9 & 0,2652 & 1,0 & 0,03777 & 0,27 & 0,41 & $239.0 \pm 0.7$ & $238.9 \pm 2.4$ & $237.8 \pm 21.1$ \\
\hline FP2.Z25 & 1,3 & 458 & 1,1 & 0,39 & 1366 & 0,05088 & 0,8 & 0,2657 & 0,9 & 0,03787 & 0,14 & 0,39 & $239.6 \pm 0.3$ & $239.2 \pm 2.1$ & $235.3 \pm 19.4$ \\
\hline
\end{tabular}

\section{Conclusions}

New finds of macrofossils (Daonella cf. longobardica, Daonella tyrolensis, ?Arpadites sp., Piarorhynchella trinodosi) and palynomorphs (Echinitosporites iliacoides, Camerosporites secatus, Nevesisporites vallatus, Duplicisporites granulatus) significantly improve the age assignment of the Reifling Formation in Liechtenstein and Vorarlberg. The correlation of this unit with the interval of the Prezzo Limestone Buchenstein Formation in the Ladinian GSSP section at Bagolino (Brack et al. 2005) is supported by biostratigraphical data and is consistent with radio-isotope age data. This age-equivalence is not unexpected since the Buchenstein and the Reifling Formations bear comparable lithologies and both units are parts of similar stratigraphical trends. The Pietra Verde levels recognised in the Reifling Formation of the study area correspond to layers of the Middle and Upper Pietra Verde intervals of the Buchenstein Formation of the Southern Alps. Finally, the Eastern Alpine Virgloria and the Gutenstein Formations are likely to be correlated with the Angolo Limestone of eastern Lombardy and Giudicarie, and the Partnach Formation of the western NCA might correspond to the Lombardian Wengen Formation. Elsewhere in the NCA the Reifling Formation also reaches higher levels (latest Ladinian or younger; Summesberger \& Wagner, 1977; Gallet et al. 1998).

We are confident that additional bio/chronostratigraphical constraints can be generated also for Reifling successions to the east of Vorarlberg. Beyond an improved stratigraphical calibration such results will be essential for a quantified assessment of the platform-basin history of the NCA and its comparison with the evolution of coeval carbonate platforms in the Southern Alps.

\section{Acknowledgements}

We would like to thank Prof. Dr. Hans Rieber (Zürich) for the determination of the ammonoids and Dr. Heinz Sulser (Engelburg) for the identification of the brachiopods. Markus Hebeisen, Rosie Roth and Heinz Lanz (all Zürich) are acknowledged for the technical assistance in preparing the daonellas and photographing the macrofossils. Irene Bucher (ETH Zürich) kindly separated the zircons of the volcanoclastic rock sample. R. Mundil acknowledges the support of the Ann and Gordon Getty Foundation. This paper benefited from reviews by G. Roghi, M. Balini and L. Krystyn.

\section{REFERENCES}

Arthaber, G. v. 1906: Die alpine Trias des Mediterran-Gebietes. In: Frech, F. (Ed.): Lethaea geognostica II. Teil, Mesozoicum Band I (Trias). Schweizerbart, Stuttgart, 223-475.

Assereto, R. 1971: Die Binodosus-Zone. Ein Jahrhundert wissenschaftlicher Gegensätze. Sitzungsberichte - Österreichische Akademie der Wissenschaften, mathematisch-naturwissenschaftliche Klasse 179, 25-53.

Assereto, R. \& Casati, P. 1965: Revisione della stratigrafia permo-triassica della Val Camonica meridionale (Lombardia). Rivista Italiana di Paleontologia e Stratigrafia 71, 999-1097.

Balini, M., Germani, D., Nicora, A. \& Rizzi, E. 2000: Ladinian / Carnian ammonoids and conodonts from the classic Schilpario - Pizzo Camino area (Lombardy): reevaluation of the biostratigraphic support to chronostratigraphy and palaeogeography. Rivista Italiana di Paleontologia e Stratigrafia 106, 19-58.

Bechstädt, T. \& Mostler, H. 1974: Mikrofazies und Mikrofauna mitteltriadischer Beckensedimente der Nördlichen Kalkalpen Tirols. GeologischPaläontologische Mitteilungen Innsbruck 4, 1-74.

Bechstädt, T. \& Mostler, H. 1976: Riff-Becken-Entwicklung in der Mitteltrias der westlichen Nördlichen Kalkalpen. Zeitschrift der Deutschen Geologischen Gesellschaft 127, 271-289.

Black, L.P., Kamo, S.L., Allen, C.M., Davis, D.W., Aleinikoff, J.N., Valley, J.W., Mundil, R., Campbell, I.H., Korsch, R.J., Williams, I.S. \& Foudoulis, C. 2004: Improved Pb-206/U-218 microprobe geochronology by the monitoring of a trace-element-related matrix effect; SHRIMP, ID-TIMS, ELAICP-MS and oxygen isotope documentation for a series of zircon standards. Chemical Geology 205, 115-140. 
Brack, P. \& Muttoni, G. 2000: High-resolution magnetostratigraphic and lithostratigraphic correlations in Middle Triassic pelagic carbonates from the Dolomites (northern Italy). Palaeogeography, Palaeoclimatology, Palaeoecology 161, 361-380.

Brack, P. \& Rieber, H. 1993: Towards a better definition of the Anisian/Ladinian boundary: New biostratigraphic data and correlation of boundary sections from the Southern Alps. Eclogae Geologicae Helvetiae 86, 415-527.

Brack, P., Rieber, H. \& Urlichs, M. 1999: Pelagic successions in the Southern Alps and their correlation with the Germanic Middle Triassic. Zentralblatt für Geologie und Paläontologie, Teil 1, 853-876.

Brack, P., Schlager, W., Stefani, M., Maurer, F. \& Kenter, J. 2000: The Seceda drill hole in the Middle Triassic Buchenstein Formation (Livinallongo Formation, Dolomites, Northern Italy) a progress report. Rivista Italiana di Paleontologia e Stratigrafia 106, 283-292.

Brack, P., Rieber, H., Nicora, A. \& Mundil, R. 2005: The Global Boundary Stratotype Section and Point (GSSP) of the Ladinian Stage (Middle Triassic) at Bagolino (Southern Alps, Northern Italy) and its implications for the Triassic time scale. Episodes 28, 233-244.

Brack, P., Rieber, H., Mundil, R., Blendinger, W. \& Maurer, F. 2007: Geometry and chronology of growth and drowning of Middle Triassic carbonate platforms (Cernera and Bivera/Clapsavon) in the Southern Alps (northern Italy). Swiss Journal of Geosciences 100, this issue, doi:10.1007/ s00015-007-1229-z.

Brandner, R. 1984: Meeresspiegelschwankungen und Tektonik in der Trias der NW-Tethys. Jahrbuch der Geologischen Bundesanstalt 126, 435-475.

Brugman, W. 1986: A palynological characterization of the Upper Scythian and Anisian of the Transdanubian Central Range (Hungary) and the Vicentinian Alps (Italy). Unpublished PhD Thesis, State University of Utrecht, 95 pp.

Condon, D.J. and Members of the Earthtime U-Pb working group. 2005: Progress report on the U-Pb interlaboratory experiment. Goldschmidt Conference, Moscow, Idaho. Geochimica et Cosmochimica Acta 69, A319.

Diener, C. 1900: Die triadische Cephalopoden-Fauna der Schiechlinghöhe bei Hallstatt. Beiträge zur Paläontologie Österreich-Ungarns und des Orient $13,42 \mathrm{pp}$.

Donofrio, D. A., Heissel, G. \& Mostler, H. 1979: Zur tektonischen und stratigraphischen Position des Martinsbühels bei Innsbruck. Geologisch-Paläontologische Mitteilungen Innsbruck, 7, 1-43.

Ferreiro Mählmann, R. 1994: Zur Bestimmung von Diagenesehöhe und beginnender Metamorphose-Temperaturgeschichte und Tektogenese des Austroalpins und Südpenninikums in Vorarlberg und Mittelbünden. Frankfurter Geowissenschaftliche Arbeiten, Serie C, Mineralogie, Band 14, 498 pp.

Gaetani, M. 1969: Osservazioni paleontologiche e stratigrafiche sull'Anisico delle Giudicarie (Trento). Rivista Italiana di Paleontologia e Stratigrafia $75,469-532$.

Gallet, Y., Krystyn, L. \& Besse, J. 1998: Upper Anisian to Eary Carnian magnetostratigraphy from the Northern Calcareous Alps (Austria). Journal of Geophysical Research 103, 605-621.

Gwinner, M.P. 1971: Geologie der Alpen. Nägele \& Obermiller, Stuttgart, 477 pp.

Hirsch, F. 1966: Etude stratigraphique du Trias moyen de la région de l'Arlberg (Alpes du Lechtal, Autriche). Unpublished PhD Thesis, Universität Zürich, 82 pp.

Hochuli, P.A. \& Roghi, G. 2002: A palynological view on the Anisian/Ladinian boundary - new results from the Seceda section (Dolomites, Northern Italy). I.U.G.S. Commission on Triassic Stratigraphy, STS/IGCP 467, Field Meeting, Veszpröm, Hungary, Program \& Abstracts, 29-30.

Kobel, M. 1969: Lithostratigraphische und sedimentologische Untersuchungen in der kalkalpinen Mitteltrias (Anisian und Ladinian) des Rätikon (Österreich und Fürstentum Liechtenstein). Mitteilungen aus dem Geologischen Institut der ETH und der Universität Zürich. Neue Folge 118, 151 pp.

Krogh, T.E. 1982: Improved accuracy of U-Pb zircon ages by the creation of more concordant systems using an air abrasion technique. Geochimica et Cosmochimica Acta 46, 637-649.
Leithner W. \& Krystyn, L. 1984: Paläogeographie, Stratigraphie und Conodonten-Biofazies des westlichen Mitterberges (Trias; Niederösterreich). Mitteilungen der Gesellschaft für Geologie- und Bergbaustudenten, Österreich 30, 177-206.

Mandl, G.W. 1984: Zur Trias des Hallstätter Faziesraumes - ein Modell am Beispiel Salzkammergut (Nördliche Kalkalpen, Österreich). Mitteilungen der Gesellschaft für Geologie- und Bergbaustudenten, Österreich 30, 133-176.

Mattinson, J.M. 2005: Zircon U-Pb Chemical Abrasion ("CA-TIMS") Method: Combined Annealing and Multi-Step Dissolution Analysis for Improved Precision and Accuracy of Zircon Ages. Chemical Geology 220, $47-66$.

Miller, H. 1965: Die Mitteltrias der Mieminger Berge mit Vergleichen zum westlichen Wettersteingebirge. Verhandlungen der Geologischen Bundesanstalt 1-2,187-212.

Mojsisovics E.v. 1893: Das Gebirge um Hallstatt, Theil I. Die Cephalopoden der Hallstätter Kalke. Abhandlungen der Kaiserlich-Königlichen Geologischen Reichsanstalt Wien 6,835 pp.

Mundil, R., Brack, P., Meier, M., Rieber, H. \& Oberli, F. 1996a: High resolution U-Pb dating of Middle Triassic volcanoclastics: Time-scale calibration and verification of tuning parameters for carbonate sedimentation. Earth and Planetary Science Letters 141, 137-151.

Mundil, R., Brack, P., Meier, M., Rieber, H. \& Oberli, F. 1996b: Erratum to "High resolution U-Pb dating of Middle Triassic volcanoclastics: Timescale calibration and verification of tuning parameters for carbonate sedimentation" (Earth and Planetary Science Letters 141 [1996], 137-151). Earth and Planetary Science Letters 143, 275-275.

Mundil, R., Zühlke, R., Bechstädt, T., Peterhänsel, A., Egenhoff, S.O., Oberli, F., Meier, M., Brack, P. \& Rieber, H. 2003: Cyclicities in Triassic platform carbonates: synchronizing radio-isotopic and orbital clocks. Terra Nova $15,81-87$.

Mundil, R., Ludwig, K.R., Metcalfe, I. \& Renne, P.R. 2004. Age and timing of the Permian mass extinctions: $\mathrm{U} / \mathrm{Pb}$ dating of closed-system zircons. Science 305, 1760-1763.

Muttoni, G., Nicora, A., Brack, P. \& Kent, D. 2004: Integrated Anisian-Ladinian boundary chronology. Palaeogeography, Palaeoclimatology, Palaeoecology 208, 85-102.

Obenholzner, J.H. 1991: Triassic volcanogenic sediments from the Southern Alps (Italy, Austria, Yugoslavia); a contribution to the "Pietra verde" problem. Sedimentary Geology 74, 157-171.

Petschik, R. 1989: Zur Wärmegeschichte im Kalkalpin Bayerns und Nordtirols (Inkohlung und Illit-Kristallinität). Frankfurter Geowissenschaftliche Arbeiten, Serie C, Mineralogie, Band 10, 259 pp.

Rüffer, T. 1995: Entwicklung einer Karbonat-Plattform: Fazies, Kontrollfaktoren und Sequenzstratigraphie in der Mitteltrias der westlichen Nördlichen Kalkalpen (Tirol, Bayern). Gaea Heidelbergensis 1, 1-282.

Rüffer, T. \& Bechstädt T. 1995: Interpretation des Deckenbaus in den westlichen Nördlichen Kalkalpen: Widerspruch zwischen tektonischen und sedimentologischen Daten. Jahrbuch der Geologischen Bundesanstalt $138,701-713$.

Rüffer T. \& Zühlke R. 1995: Sequence stratigraphy and sea-level changes in the Early to Middle Triassic of the Alps: A global comparison. In: Haq, B.U. (Ed.): Sequence stratigraphy and depositional response to eustatic, tectonic and climatic forcing. Kluwer Academic Publishers, Dordrecht, 161-207.

Sarnthein, M. 1965: Sedimentologische Profilreihen aus mitteltriadischen Karbonatgesteinen der Kalkalpen nördlich und südlich von Innsbruck. Verhandlungen der Geologischen Bundesanstalt 1-2, 119-162.

Sarnthein, M. 1966: Sedimentologische Profilreihen aus der mitteltriadischen Karbonatgesteinen der Kalkalpen nördlich und südlich von Innsbruck. I. Fortsetzung. Berichte des Naturwissenschaftlich-Medizinischen Vereins in Innsbruck 54, 33-59.

Schatz, W. 2001: Revision der Untergattung Daonella (Pichlerella) (Bivalvia, Ladin). Eclogae geologicae Helvetiae 94, 389-398.

Schatz, W. 2004: Revision of the subgenus Daonella (Arzelella) (Halobiidae; Middle Triassic). Journal of Palaeontology 78, 300-316. 
Schatz, W. 2005: Taxonomie, Paläoökologie und biostratigraphische Anwendungen der Daonellen (Bivalvia, Mollusca) aus der Mitteltrias Europas. Schweizerische Paläontologische Abhandlungen 125, 180 pp.

Summesberger, H. \& Wagner, L. 1972: Der Stratotypus des Anis (Trias). Annalen des Naturhistorischen Museums in Wien 76, 515-538.

Tatzreiter, F. 2001: Noetlingites strombecki (Griepenkerl, 1860) und die stratigraphische Stellung der Grossreiflinger Ammonitenfaunen (Anis, Steiermark/Österreich). Mitteilungen der Gesellschaft der Geologie- und Berg-

Tollmann, A. 1985: Geologie von Österreich. Bd. II Ausserzentralalpiner Anteil. F. Deuticke, Wien, 710 pp.

Trümpy, D. 1916: Geologische Untersuchungen im westlichen Rätikon. Beiträge zur geologischen Karte der Schweiz. Neue Folge 46, 164 pp.

Van der Eem, J.G.L.A. 1983: Aspects of Middle and Late Triassic palynology 6. Palynological investigation in the Ladinian and Lower Karnian of the western Dolomites, Italy. Review of Palaeobotany and Palynology 39, $165-286$.
Vidal, H. 1953: Neue Ergebnisse zur Stratigraphie und Tektonik des nordwestlichen Wettersteingebirges und seines nördlichen Vorlandes. Geologica Bavarica 17, 56-88.

Wiedenbeck, M., Alle, P., Corfu, F., Griffin, W.L., Meier, M., Oberli, F., Von Quadt, A., Roddick, J.C. \& Spiegel, W. 1995: Three natural zircon standards for U-Th-Pb, Lu-Hf, trace element and REE analyses. Geostandards Newsletter 19, 1-23.

Manuscript received February 6, 2006

Manuscript accepted September 14, 2007

Editorial handling: E. Erba \& J.-P. Billon-Bruyat

Published Online First November 14, 2007

\section{Plate I.}

Macrofossils from the Reifling Formation of Liechtenstein (Kulm and Nospitz sections) and Austria (Blankuskopf and Flexenpass sections). Scale bars: $1 \mathrm{~cm}$. 1) Daonella cf. longobardica KiтTL 1912. Sinistral valve; a, b: positive, negative. Flexenpass, PIMUZ 24674. 2) Daonella tyrolensis MoJsisovics 1874. Dextral valve. Nospitz, PIMUZ 24670b. 3) Daonella tyrolensis Mossisovics 1874. Dextral valve; a, b: negative, positive. Blankuskopf, PIMUZ 24676. 4) Daonella tyrolensis MoJsIsovics 1874. Dextral valve. Nospitz, PIMUZ 24670a. 5) Daonella tyrolensis MoJsIsovics 1874. ?Dextral valve. Flexenpass, PIMUZ 24675. 6) cf. Mentzelia sp. a, b: lateral, ventral views. Blankuskopf, PIMUZ 24673. 7) Piarorhynchella trinodosi (BITTNER 1890) DAGYs 1974. a, b, c: dorsal, lateral, anterior views. Blankuskopf, PIMUZ 24671. 8) ?Arpadites sp. a, b, c, d: sinistral, dextral, apertural, ventral views. Kulm, PIMUZ 24677. 

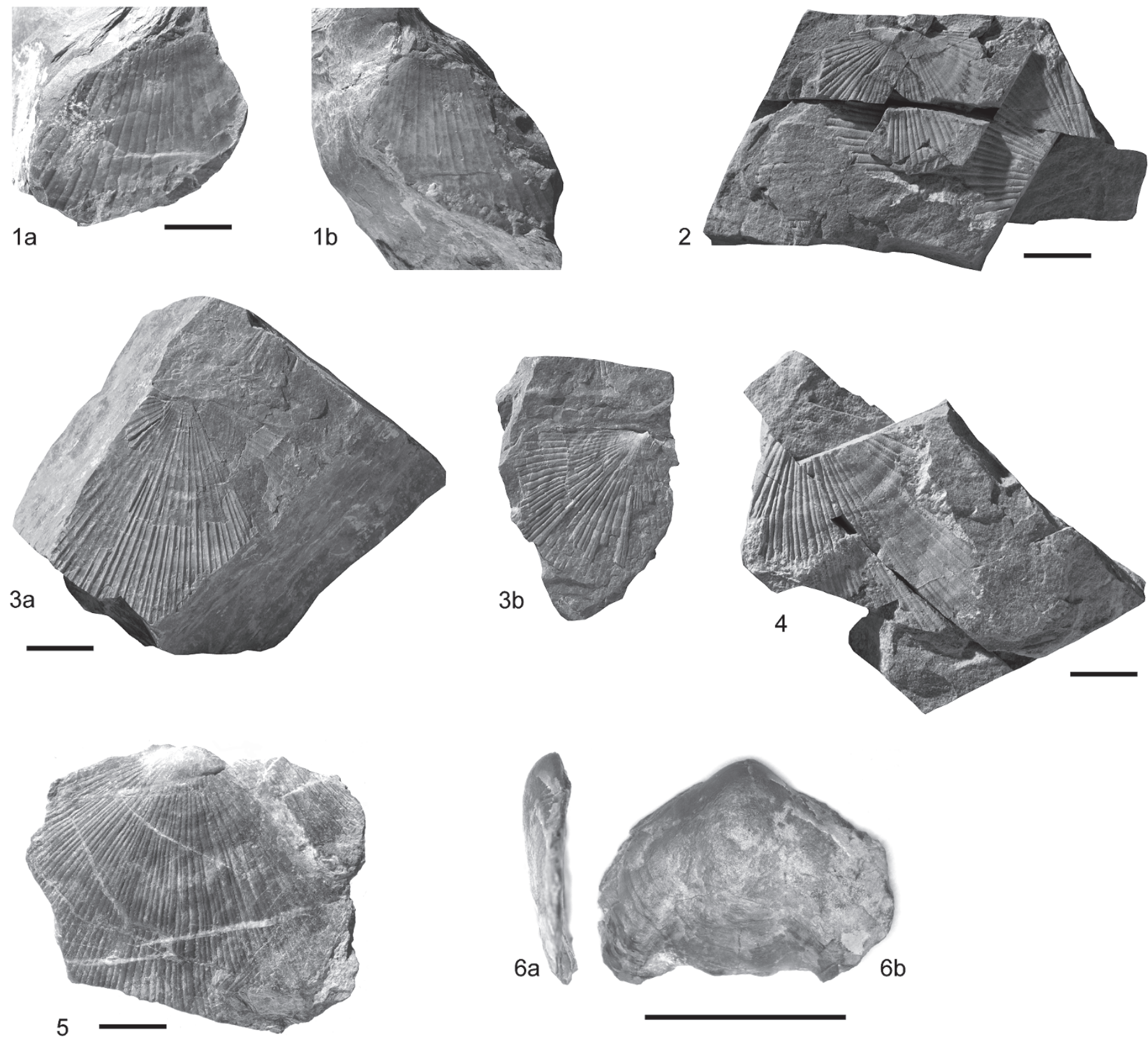

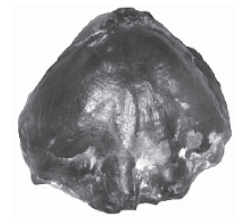

$7 a$

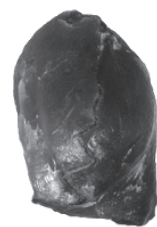

$7 b$

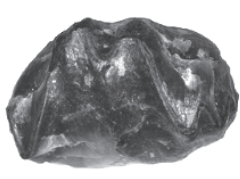

7c

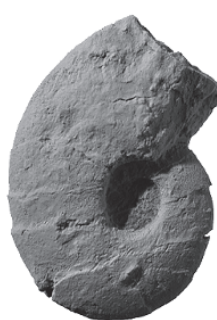

$8 a$

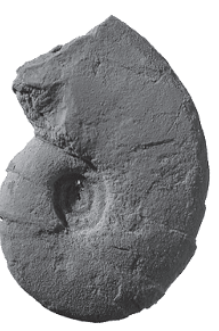

$8 b$

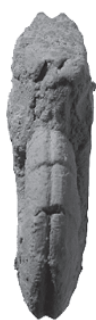

$8 c$

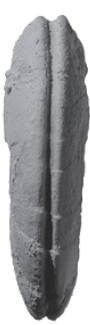

$8 d$ 


\section{Plate II.}

Palynomorphs from the Reifling Formation of Liechtenstein (Kulm section) and Austria (Blankuskopf section). Scale bars: 10 $\mu \mathrm{m}$ (1-11, 13-17, 19, 20); 20 $\mu \mathrm{m}$ (12, 18). Optical microscope images.

1a, b) Echinitosporites iliacoides SchULZ \& Krutzsch 1961, slide K1c. 2) Partitisporites sp., slide BP23. 3) Camerosporites secatus LeschIK 1955, slide K1b. 4) Baculatisporites sp., slide K1c. 5) Echinitosporites iliacoides SchUlz \& KRUTZSCH 1961, slide K1b. 6) Echinitosporites iliacoides SCHULz \& KRUTZSCH 1961, slide K1. 7) Duplicisporites granulatus (LESCHIK 1955) VAN DER EEM 1983, slide K1b. 8) Duplicisporites granulatus (LESCHIK 1955) VAN DER EEM 1983, slide K1. 9) Concavisporites sp., slide K1. 10a, b) Echinitosporites iliacoides SchUlz \& KRUTZSCH 1961, slide K1c. 11) Gordonispora fossulata (BALME 1970) VAN DER EEM 1983, slide K1c. 12) Porcellispora longdonensis (Clarke1965) SCHEURING 1970, slide K1. 13) Aratrisporites cf. parvispinosus LeSCHIK 1955, slide K1. 14) Aratrisporites scabratus Klaus 1960, slide K1.15) Aratrisporites scabratus Klaus 1960, slide K1c. 16) Calamospora sp., slide K1. 17) Ovalipollis sp., slide K1. 18) Ovalipollis sp., slide K1b. 19) Striatoabieites sp., slide K1b. 20) Nevesisporites vallatus DE JERSEY \& PATEN 1964, slide K1.

454 T. Brühwiler et al. 

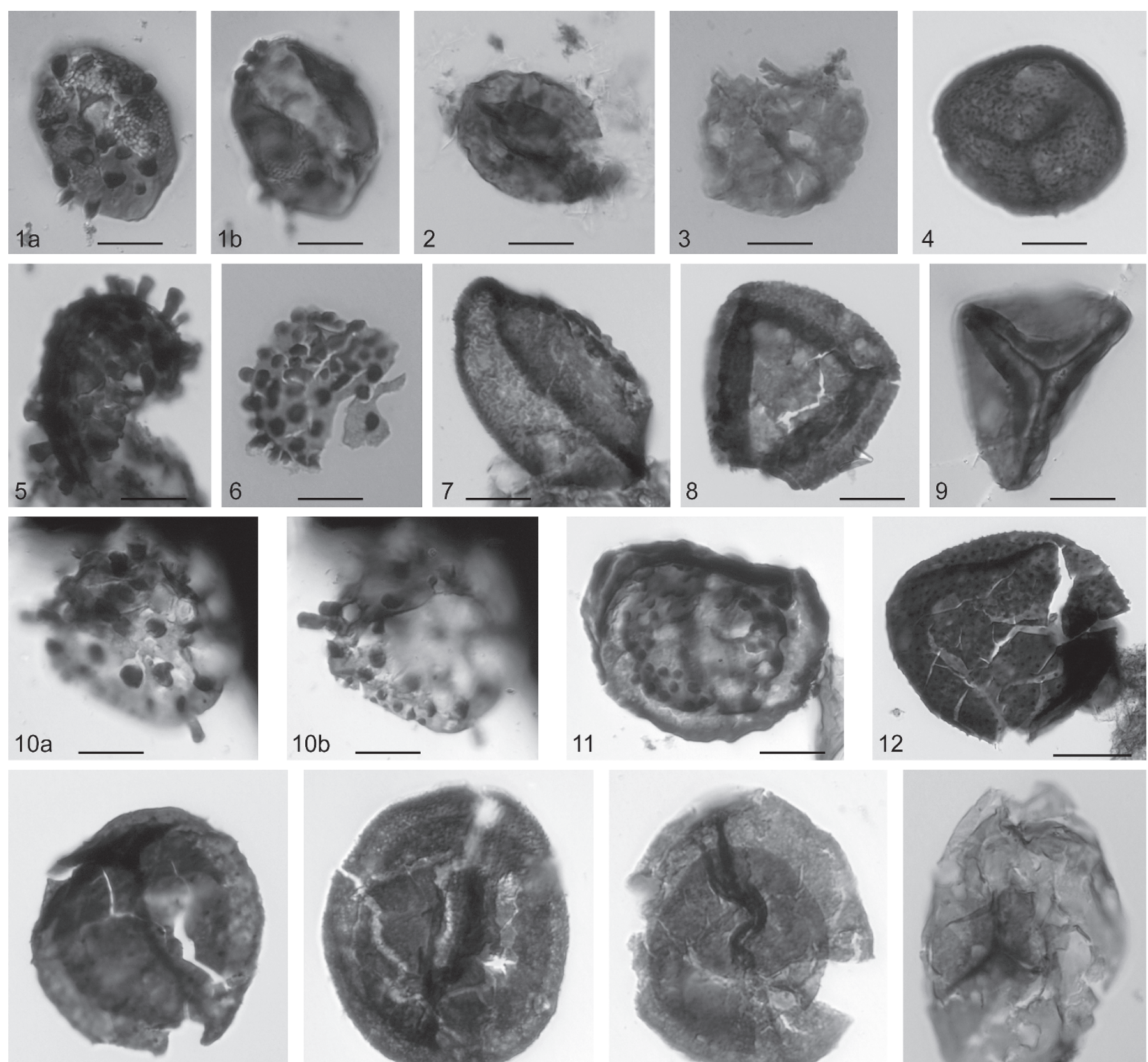

13
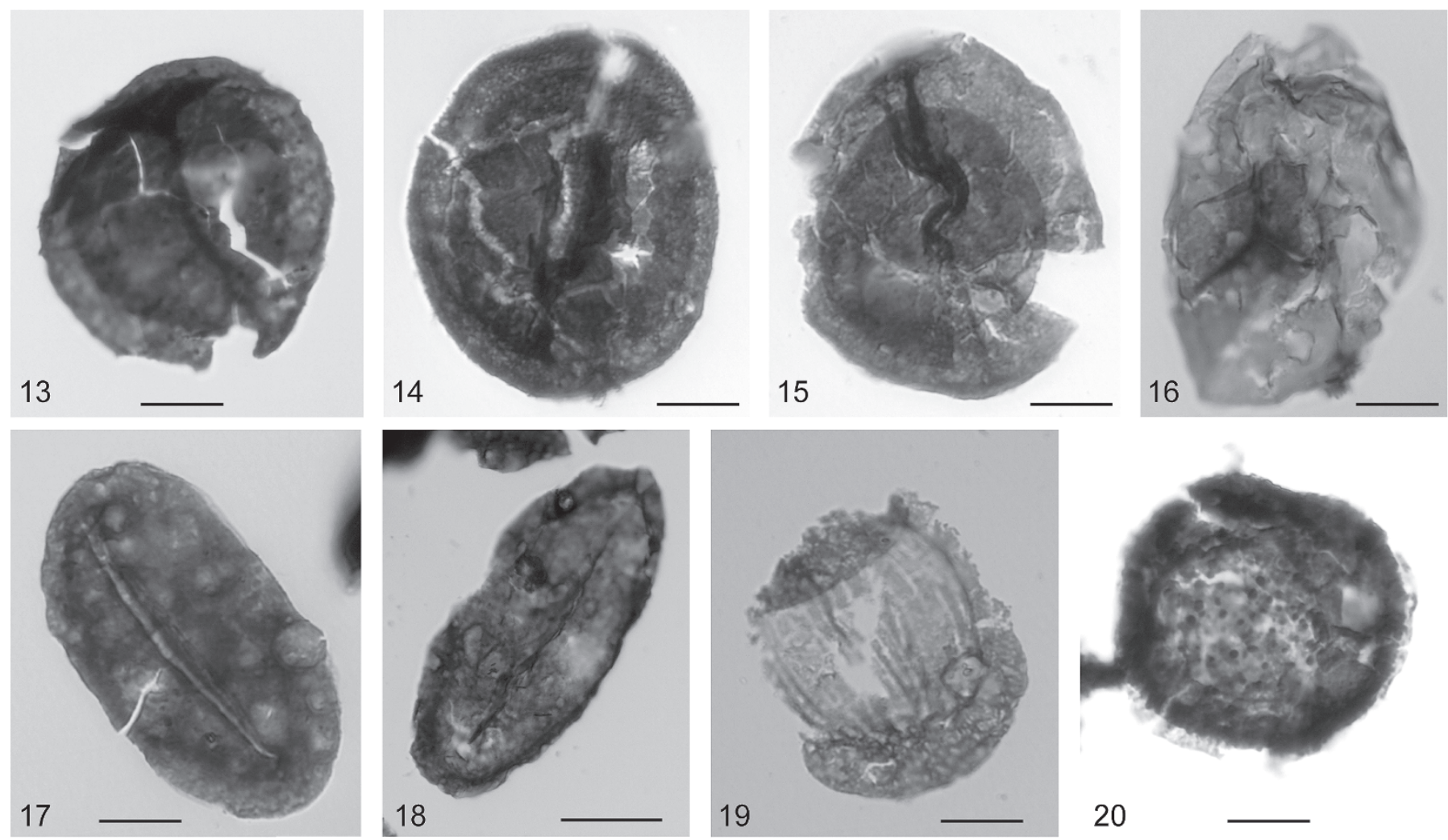